\title{
Influencing factors in the satellitism test of Haemophilus influenzae and Haemophilus parainfluenzae supplemented V factor by Staphylococcus aureus
}

\author{
YuXi \\ School of Life Sciences, Zhengzhou University \\ Hexuan Wang \\ Zhengzhou No. 47 Middle \& High School \\ Shanmei Wang \\ Department of Clinical Laboratory, Henan Provincial People's Hospital \\ Xuxiao Wu \\ R\&D Center, Autobio Diagnostics Co.,Ltd \\ Zeyu Wang ( $\sim$ pine8844@126.com) \\ Autobio Diagnostics Co.Ltd https://orcid.org/0000-0002-5112-9555
}

\section{Research article}

Keywords: False positives, Haemophilus influenzae, False negatives, Haemophilus parainfluenzae, Satellitism test, Staphylococcus aureus

Posted Date: March 24th, 2020

DOI: https://doi.org/10.21203/rs.3.rs-17724/v1

License: (c) (i) This work is licensed under a Creative Commons Attribution 4.0 International License. Read Full License 


\section{Abstract}

Background: Many factors affecting satellitism test are not clear, and it is difficult to avoid misidentified even if the medium is properly selected. We investigated the factors that cause false positives of Haemophilus influenzae and false negatives of Haemophilus parainfluenzae in the satellitism test supplemented V factor by Staphylococcus aureus.

Methods: $\mathrm{H}$. influenzae (four reference strains and 47 clinical isolates), H. parainfluenzae (two reference strains and 67 clinical isolates), four different media, and two strains of $\mathrm{S}$. aureus activated on two different media were involved in this study.

Results: The type of medium used to activate $\mathrm{S}$. aureus was the most common factor causing false positives of $\mathrm{H}$. influenzae, followed by the strain of S. aureus, and again the type of medium used for the experiment. The production of false negatives of $\mathrm{H}$. parainfluenzae was only related to the medium used in the experiment.

Conclusions: Tryptic soy agar and S. aureus (ATCC 25923) activated with nutrient agar should be used in the satellitism test for Haemophilus spp. to improve the accuracy of the test.

\section{Introduction}

Haemophilus influenzae is an important pathogen that causes community-acquired pneumonia, nosocomial pneumonia, chronic bronchitis in older adults, and upper respiratory tract infections in children. Encapsulated $\mathrm{H}$. influenza, such as type b, is more virulent than unencapsulated strains and can cause diseases such as meningitis, pneumonia, epiglottitis, and sepsis [1, 2]. However, invasive infections are more often attributed to unencapsulated strains since the introduction of the $\mathrm{H}$. influenzae serotype b conjugate vaccines $[3,4]$.

In contrast, Haemophilus parainfluenzae may colonize the human upper respiratory tract and is usually considered to be a member of the normal oral microflora [5-7]. It is less pathogenic but does cause occasional cases of bacterial endocarditis [8, 9], sepsis [10], urethritis, upper respiratory tract infections, intracerebral abscess [11], etc.

Discrimination assays for $\mathrm{H}$. influenzae and $\mathrm{H}$. parainfluenzae, such as the biochemical identification system, matrix-assisted laser desorption ionization time-of-flight mass spectrometry (MALDI-TOF MS), PCR assays and 16S rDNA gene sequencing all have reliability problems to various degrees [12-15]. Although a cryptic species of Haemophilus spp. is phylogenetically close to, but distinct from, $\mathrm{H}$. parainfluenzae, especially they both require $V$ factor (NAD) but not $X$ factor (heme) to grow [16], the satellitism test is the classic way to confirm Haemophilus spp. [17], and it is still commonly used in clinical laboratories because of its convenience. In practice, we found it was more often challenging to distinguish $\mathrm{H}$. influenzae from $\mathrm{H}$. parainfluenzae by the satellitism test supplemented NAD by Staphylococcus aureus than by discs impregnated with NAD, primarily due to false positives of H. influenzae and false negatives of $\mathrm{H}$. parainfluenzae.

This study aimed to identify the factors that influenced the satellitism test to distinguish $\mathrm{H}$. influenzae from $\mathrm{H}$. parainfluenzae supplemented NAD by Staphylococcus aureus and investigated scientific approaches to improve the accuracy of the results.

\section{Methods}

\section{Bacterial strains}

Eight reference strains were obtained from the ATCC: four strains of H. influenzae (ATCC 10211, ATCC 9766, ATCC 49247, and ATCC 19418), two strains of H. parainfluenzae (ATCC 9796 and ATCC 33392), and two strains of Staphylococcus aureus (ATCC 25923 and ATCC 29213). In addition, 47 clinical isolates of $\mathrm{H}$. influenzae and 67 clinical isolates of $\mathrm{H}$. parainfluenzae were preserved in the Laboratory of Microbial Culture Collection of Autobio Diagnostics Co., Ltd. All of these clinical isolates were identified by the Bruker Microflex (Bruker Daltonics, Bremen, Germany) with scores more than 2.0, and confirmed by 16S rDNA gene sequencing (Sangon Biotech, Shanghai, China).

\section{Media}

Muller Hinton agar used in the study was derived from two manufacturers, OXOID (lot 2307248, Basingstoke, UK) and BD (lot 9002585, Becton Dickinson, Franklin Lakes, USA). Tryptic soy agar was also obtained from two manufacturers, BD (lot 6286786, 
Becton Dickinson, Franklin Lakes, USA) and Huankai Microbial (lot 1070181, Guangzhou, China). These media powders were processed into agar plates.

Nutrient agar plates (NAPs), blood agar plates (BAPs) and chocolate agar plates (CAPs) were all obtained from Autobio (Zhengzhou, China) as lots 20191209B, 20191210B and 20191125B, respectively. Beef extract power (lot 20190710, Baijia, Luoyang, China) was added to both tryptic soy agar samples at a final concentration of $0.2 \%$, and then they were processed into agar plates.

\section{Satellitism test}

$\mathrm{H}$. influenzae and $\mathrm{H}$. parainfluenzae were both activated on CAPs, while S. aureus was activated on BAPs and NAPs. The satellitism test was carried out with reference to the literature [18] briefly described as follows: first, a loopful of activated Haemophilus colonies was suspended in $2 \mathrm{ml}$ of sterile physiologic saline; second, the bacterial suspension was spread evenly onto Muller Hinton agar plates (MHAPs), NAPs and tryptic soy agar plates (TSAPs) using sterile swabs; third, a pure culture of S. aureus was streaked across each of the inoculated plates; and finally, the inoculated plates were placed in a carbon dioxide incubator at $35-37^{\circ} \mathrm{C}$ for $18-24 \mathrm{~h}$ and then examined for growth and satellite colonies. Satellite colonies were defined as small colonies growing in the vicinity of the $\mathrm{S}$. aureus, where the tested bacteria had been inoculated.

\section{Results}

\section{Satellitism test of reference strains}

The results (Table 1) showed that the following three conditions were less likely to produce false positives: using S. aureus activated on NAPs rather than activated on BAPs, using ATCC 25923 rather than ATCC 29213, and using TSAPs rather than TSAPs supplemented with beef extract power. Strictly speaking, the media used in the satellitism test were free of false positives and false negatives only under three conditions: one was to use TSAPs (Huankai) and only ATCC 25923 activated on NAPs, while the other two were to use MHAPs from either manufacturer and only ATCC 29213 activated on NAPs. In fact, there were very few satellite colonies in the case of " \pm ", which was very different from " + " and might be considered negative.

In this way, TSAPs (BD) and MHAPs from both manufacturers could be used in the satellitism test of six reference strains of Haemophilus spp. with ATCC 25923 activated on NAPs. Furthermore, only H. parainfluenzae (ATCC 9796) did not grow on NAPs in all four cases, meaning false-negative findings. In addition, the results also showed that the same type of media from different manufacturers had so little influence on the satellitism test results that this factor could be ignored. 
Table 1

Results of the satellitism test of six reference strains on different media*

\begin{tabular}{|c|c|c|c|c|c|c|c|c|}
\hline Media & $\begin{array}{l}\text { S. } \\
\text { aureus }\end{array}$ & $\begin{array}{l}\text { Media for } \\
\text { activating } \\
\text { S. aureus }\end{array}$ & $\begin{array}{l}\mathrm{H} . \\
\text { influenzae } \\
\text { (ATCC } \\
\text { 10211) }\end{array}$ & $\begin{array}{l}\mathrm{H} . \\
\text { influenzae } \\
\text { (ATCC } \\
9766 \text { ) }\end{array}$ & $\begin{array}{l}\mathrm{H} . \\
\text { influenzae } \\
\text { (ATCC } \\
49247 \text { ) }\end{array}$ & $\begin{array}{l}\text { H. } \\
\text { Influenzae } \\
\text { (ATCC } \\
\text { 19418) }\end{array}$ & $\begin{array}{l}\text { H. } \\
\text { parainfluenzae } \\
\text { (ATCC 9796) }\end{array}$ & $\begin{array}{l}\text { H. } \\
\text { parainfluenzae } \\
\text { (ATCC 33392) }\end{array}$ \\
\hline \multirow[t]{4}{*}{$\begin{array}{l}\text { MHAPs } \\
\text { (OXOID) }\end{array}$} & $\begin{array}{l}\text { ATCC } \\
29213\end{array}$ & BAPs & ++ & + & + & - & ++ & ++ \\
\hline & $\begin{array}{l}\text { ATCC } \\
25923\end{array}$ & BAPs & ++ & + & + & - & ++ & ++ \\
\hline & $\begin{array}{l}\text { ATCC } \\
29213\end{array}$ & NAPs & - & - & - & - & ++ & ++ \\
\hline & $\begin{array}{l}\text { ATCC } \\
25923\end{array}$ & NAPS & \pm & - & - & - & ++ & ++ \\
\hline \multirow[t]{4}{*}{$\begin{array}{l}\text { MHAPs } \\
\text { (BD) }\end{array}$} & $\begin{array}{l}\text { ATCC } \\
29213\end{array}$ & BAPs & ++ & + & ++ & - & ++ & ++ \\
\hline & $\begin{array}{l}\text { ATCC } \\
25923\end{array}$ & BAPs & ++ & + & + & - & ++ & ++ \\
\hline & $\begin{array}{l}\text { ATCC } \\
29213\end{array}$ & NAPs & - & - & - & - & ++ & ++ \\
\hline & $\begin{array}{l}\text { ATCC } \\
25923\end{array}$ & NAPs & \pm & - & - & - & ++ & ++ \\
\hline \multirow[t]{4}{*}{ NAPs } & $\begin{array}{l}\text { ATCC } \\
29213\end{array}$ & BAPs & + & + & + & + & - & ++ \\
\hline & $\begin{array}{l}\text { ATCC } \\
25923\end{array}$ & BAPs & + & \pm & \pm & \pm & - & ++ \\
\hline & $\begin{array}{l}\text { ATCC } \\
29213\end{array}$ & NAPs & + & \pm & \pm & \pm & - & ++ \\
\hline & $\begin{array}{l}\text { ATCC } \\
25923\end{array}$ & NAPs & + & \pm & \pm & \pm & - & ++ \\
\hline \multirow[t]{4}{*}{ TSAPs (BD) } & $\begin{array}{l}\text { ATCC } \\
29213\end{array}$ & BAPs & ++ & ++ & + & + & ++ & ++ \\
\hline & $\begin{array}{l}\text { ATCC } \\
25923\end{array}$ & BAPs & ++ & ++ & + & \pm & ++ & ++ \\
\hline & $\begin{array}{l}\text { ATCC } \\
29213\end{array}$ & NAPs & + & \pm & - & - & ++ & ++ \\
\hline & $\begin{array}{l}\text { ATCC } \\
25923\end{array}$ & NAPs & \pm & - & - & \pm & ++ & ++ \\
\hline \multirow{4}{*}{$\begin{array}{l}\text { TSAPs (BD) } \\
\text { Supplemented } \\
\text { with beef } \\
\text { extract }\end{array}$} & $\begin{array}{l}\text { ATCC } \\
29213\end{array}$ & BAPs & ++ & ++ & ++ & + & ++ & ++ \\
\hline & $\begin{array}{l}\text { ATCC } \\
25923\end{array}$ & BAPs & ++ & ++ & + & \pm & ++ & ++ \\
\hline & $\begin{array}{l}\text { ATCC } \\
29213\end{array}$ & NAPs & + & \pm & \pm & \pm & ++ & ++ \\
\hline & $\begin{array}{l}\text { ATCC } \\
25923\end{array}$ & NAPs & + & - & - & - & ++ & ++ \\
\hline $\begin{array}{l}\text { TSAPs } \\
\text { (Huankai) }\end{array}$ & $\begin{array}{l}\text { ATCC } \\
29213\end{array}$ & BAPs & ++ & + & \pm & - & ++ & ++ \\
\hline
\end{tabular}




\begin{tabular}{|c|c|c|c|c|c|c|c|c|}
\hline Media & $\begin{array}{l}\text { S. } \\
\text { aureus }\end{array}$ & $\begin{array}{l}\text { Media for } \\
\text { activating } \\
\text { S. aureus }\end{array}$ & $\begin{array}{l}\text { H. } \\
\text { influenzae } \\
\text { (ATCC } \\
\text { 10211) }\end{array}$ & $\begin{array}{l}\text { H. } \\
\text { influenzae } \\
\text { (ATCC } \\
9766 \text { ) }\end{array}$ & $\begin{array}{l}\text { H. } \\
\text { influenzae } \\
\text { (ATCC } \\
49247 \text { ) }\end{array}$ & $\begin{array}{l}\text { H. } \\
\text { Influenzae } \\
\text { (ATCC } \\
\text { 19418) }\end{array}$ & $\begin{array}{l}\mathrm{H} . \\
\text { parainfluenzae } \\
\text { (ATCC 9796) }\end{array}$ & $\begin{array}{l}\text { H. } \\
\text { parainfluenzae } \\
\text { (ATCC 33392) }\end{array}$ \\
\hline & $\begin{array}{l}\text { ATCC } \\
25923\end{array}$ & BAPs & ++ & + & \pm & - & ++ & ++ \\
\hline & $\begin{array}{l}\text { ATCC } \\
29213\end{array}$ & NAPs & + & \pm & \pm & \pm & ++ & ++ \\
\hline & $\begin{array}{l}\text { ATCC } \\
25923\end{array}$ & NAPs & - & - & - & - & ++ & ++ \\
\hline \multirow{4}{*}{$\begin{array}{l}\text { TSAPs } \\
\text { (Huankai) } \\
\text { Supplemented } \\
\text { with beef } \\
\text { extract }\end{array}$} & $\begin{array}{l}\text { ATCC } \\
29213\end{array}$ & BAPs & ++ & + & + & + & ++ & ++ \\
\hline & $\begin{array}{l}\text { ATCC } \\
25923\end{array}$ & BAPs & ++ & + & + & - & ++ & ++ \\
\hline & $\begin{array}{l}\text { ATCC } \\
29213\end{array}$ & NAPs & + & + & \pm & \pm & ++ & ++ \\
\hline & $\begin{array}{l}\text { ATCC } \\
25923\end{array}$ & NAPs & \pm & - & - & - & ++ & ++ \\
\hline
\end{tabular}

\section{Satellitism test of clinical isolates}

The results (Table 2) of the clinical isolates were similar to those of the reference strains, except that some of the H. parainfluenzae isolates did not grow or grew more poorly on MHAPs than on NAPs. The growth performance of $\mathrm{H}$. parainfluenzae isolates on different media was obviously different, especially for TSAPs, where its growth was the best. There was only one isolate that grew slightly worse than all of the other H. parainfluenzae isolates on all four TSAPs (BD) conditions. In addition, the H. parainfluenzae isolates grew better on TSAPs.

However, the growth performance of $\mathrm{H}$. influenzae was significantly different among the four conditions on each medium. Although one isolate of $\mathrm{H}$. influenzae was misidentified as H. parainfluenzae on TSAPs (BD), overall, the use of TSAPs and ATCC 25923 activated on NAPs significantly reduced false positives of $\mathrm{H}$. influenzae in the satellitism test. 
Table 2

Results of the satellitism test of 114 clinical isolates of Haemophilus spp. on different media

\begin{tabular}{|c|c|c|c|c|}
\hline Media & S. aureus & $\begin{array}{l}\text { Media for } \\
\text { activating } \\
\text { S. aureus }\end{array}$ & $\begin{array}{l}\text { No. of negative results of } \mathrm{H} \text {. } \\
\text { influenzae * } \\
(47)\end{array}$ & $\begin{array}{l}\text { No. of positive results of } \mathrm{H} \text {. } \\
\text { parainfluenzae ** } \\
(67)\end{array}$ \\
\hline \multirow[t]{4}{*}{$\begin{array}{l}\text { MHAPs } \\
\text { (OXOID) }\end{array}$} & $\begin{array}{l}\text { ATCC } \\
29213\end{array}$ & BAPs & 2 & 41 \\
\hline & $\begin{array}{l}\text { ATCC } \\
25923\end{array}$ & BAPs & 6 & 41 \\
\hline & $\begin{array}{l}\text { ATCC } \\
29213\end{array}$ & NAPs & 27 & 41 \\
\hline & $\begin{array}{l}\text { ATCC } \\
25923\end{array}$ & NAPs & 32 & 41 \\
\hline \multirow[t]{4}{*}{$\begin{array}{l}\text { MHAPs } \\
\text { (BD) }\end{array}$} & $\begin{array}{l}\text { ATCC } \\
29213\end{array}$ & BAPs & 2 & 42 \\
\hline & $\begin{array}{l}\text { ATCC } \\
25923\end{array}$ & BAPs & 5 & 42 \\
\hline & $\begin{array}{l}\text { ATCC } \\
29213\end{array}$ & NAPs & 26 & 42 \\
\hline & $\begin{array}{l}\text { ATCC } \\
25923\end{array}$ & NAPs & 30 & 42 \\
\hline \multirow[t]{4}{*}{ NAPs } & $\begin{array}{l}\text { ATCC } \\
29213\end{array}$ & BAPs & 12 & 55 \\
\hline & $\begin{array}{l}\text { ATCC } \\
25923\end{array}$ & BAPs & 24 & 55 \\
\hline & $\begin{array}{l}\text { ATCC } \\
29213\end{array}$ & NAPs & 30 & 55 \\
\hline & $\begin{array}{l}\text { ATCC } \\
25923\end{array}$ & NAPs & 33 & 55 \\
\hline \multirow[t]{4}{*}{ TSAPs (BD) } & $\begin{array}{l}\text { ATCC } \\
29213\end{array}$ & BAPs & 15 & $67 \star \star \star$ \\
\hline & $\begin{array}{l}\text { ATCC } \\
25923\end{array}$ & BAPs & 17 & 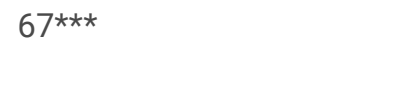 \\
\hline & $\begin{array}{l}\text { ATCC } \\
29213\end{array}$ & NAPs & 40 & 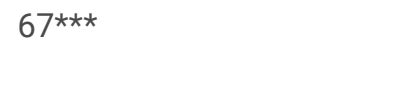 \\
\hline & $\begin{array}{l}\text { ATCC } \\
25923\end{array}$ & NAPs & 46 & 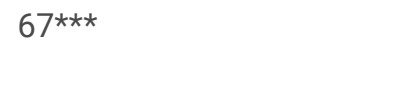 \\
\hline \multirow{4}{*}{$\begin{array}{l}\text { TSAPs (BD) } \\
\text { Supplemented with beef } \\
\text { extract }\end{array}$} & $\begin{array}{l}\text { ATCC } \\
29213\end{array}$ & BAPs & 6 & 67 \\
\hline & $\begin{array}{l}\text { ATCC } \\
25923\end{array}$ & BAPs & 7 & 67 \\
\hline & $\begin{array}{l}\text { ATCC } \\
29213\end{array}$ & NAPs & 29 & 67 \\
\hline & $\begin{array}{l}\text { ATCC } \\
25923\end{array}$ & NAPs & 31 & 67 \\
\hline \multirow[t]{2}{*}{$\begin{array}{l}\text { TSAPS } \\
\text { (Huankai) }\end{array}$} & $\begin{array}{l}\text { ATCC } \\
29213\end{array}$ & BAPs & 17 & 67 \\
\hline & $\begin{array}{l}\text { ATCC } \\
25923\end{array}$ & BAPs & 20 & 67 \\
\hline
\end{tabular}




\begin{tabular}{|lllll|}
\hline Media & S. aureus & $\begin{array}{l}\text { Media for } \\
\text { activating } \\
\text { S. aureus }\end{array}$ & $\begin{array}{l}\text { No. of negative results of } \mathbf{H} . \\
\text { influenzae * } \\
(\mathbf{4})\end{array}$ & $\begin{array}{l}\text { No. of positive results of } \mathbf{H} . \\
\text { parainfluenzae ** } \\
(67)\end{array}$ \\
\hline & $\begin{array}{l}\text { ATCC } \\
29213\end{array}$ & NAPs & 43 & 67 \\
\hline $\begin{array}{l}\text { ATCC } \\
25923\end{array}$ & NAPs & 47 & 67 \\
\hline $\begin{array}{l}\text { TSAPs (Huankai) } \\
\text { Supplemented with beef } \\
\text { extract }\end{array}$ & $\begin{array}{l}\text { ATCC } \\
29213\end{array}$ & BAPs & 8 & 67 \\
\hline $\begin{array}{l}\text { ATCC } \\
25923\end{array}$ & BAPs & 10 & 67 \\
\hline $\begin{array}{l}\text { ATCC } \\
29213\end{array}$ & NAPs & 31 & 67 \\
\hline $\begin{array}{l}\text { ATCC } \\
25923\end{array}$ & NAPs & 38 & 67 \\
\hline
\end{tabular}

* Negative results: few or no satellite colonies

** Positive results: more or many satellite colonies

$\star \star \star$ One of them had relatively few satellite colonies

\section{Discussion}

There are two methods of the satellitism test of Haemophilus spp., one is to use discs containing $\mathrm{V}$ factor, $\mathrm{X}$ factor or both, and the other is to use $\mathrm{S}$. aureus to provide $\mathrm{V}$ factor, and to use blood in the medium containing blood to provide $\mathrm{X}$ factor. The latter is more widely used because it is easy to use.

Improper use of media can easily lead to false identification. Trace amounts of hemin in the medium or in a heavy inoculum are responsible for false positives of $\mathrm{H}$. influenzae, and insufficient medium to maintain the growth of bacteria is the cause of false negatives of $\mathrm{H}$. parainfluenzae $[19,20]$

Our research suggested that among the factors that caused positive results in the satellitism tests of Haemophilus, such as the type of medium, different strains of S. aureus, and type of medium used for activating S. aureus, the latter had a much greater impact than the other factors. The use of BAPs to activate $\mathrm{S}$. aureus was most likely to produce false positives for $\mathrm{H}$. influenzae in the satellitism test. S. aureus uses the iron-regulated surface-determinant (Isd) system to acquire iron ions in blood cells. S. aureus binds hemoglobin through the surface-exposed hemoglobin receptor IsdB [21-23]. Thus, hemoglobin that has not yet been transported through the peptidoglycan layer can be released due to binding instability. This may be why the satellitism test using BAPs-activated S. aureus is prone to false positives.

Furthermore, our research also found that the effect of different strains of S. aureus on H. influenzae on MHAPs and TSAPs might be reversed, even if they were all activated on NAPs. This might be because the stability of the binding between hemoglobin and IsdB of ATCC 25923 was not as strong as that of ATCC 29213 on MHAPs, and the opposite was true for the satellitism test using TSAPs.

The beef extract powder test we performed showed that even if S. aureus was activated on NAPs, TSAPs supplemented with beef extract powder were more likely to grow $\mathrm{H}$. influenzae colonies than the ones not supplemented. This might be why the satellitism tests on MHAPs or NAPs were more likely to produce false positives for $\mathrm{H}$. influenzae, perhaps because both media formulations contained beef extract powder and trace heme remained in the beef extract powder due to incomplete cleansing of blood cells before beef processing. However, it is unknown why a few colonies of $\mathrm{H}$. influenzae grow on TSAPs under the same condition, and further research is needed.

Although in our experiments the reference strains of $\mathrm{H}$. parainfluenzae were more likely to produce false negatives on NAPs, the clinical isolates were more likely to produce false negatives on MHAPs, with some discrepancies. This suggests that neither MHAPs 
nor NAPs are sufficient to sustain the growth of all strains of H. parainfluenzae in the satellitism test. However, from another aspect, the amount of NAD required for the growth of $\mathrm{H}$. parainfluenzae was five times that required for the growth of $\mathrm{H}$. influenzae (1$5 \mathrm{pg} / \mathrm{ml}$ vs. $0.2-1 \mathrm{pg} / \mathrm{ml}$ ) [24], which can explain why some strains of $\mathrm{H}$. parainfluenzae fail to grow on MHAPs or NAPs. This might be because NAD produced from $\mathrm{S}$. aureus metabolism on MHAPs or NAPs is insufficient to meet the needs of some strains of $\mathrm{H}$. parainfluenzae, and the growth of these strains on TSAPs might be due to the generation of sufficient NAD.

\section{Conclusions}

False positives of $\mathrm{H}$. influenzae and false negatives of $\mathrm{H}$. parainfluenzae in the satellitism test are relatively common due to the use of improper media and application methods. To ensure the accuracy of the results, we recommend that TSAPs and S. aureus (ATCC 25923) activated on NAPs should be used in the satellitism test for Haemophilus spp.

\section{Declarations}

\section{Ethics approval and consent to participate}

No formal ethics approval was required in the study and informed written consent was waived by the Ethics Committee of Autobio Diagnostics Co., because the study is only about six reference strains and 114 clinical isolates of in-depth study, which does not involve in the human body, human specimens, or personal information.

\section{Consent for publication}

Not applicable.

\section{Availability of data and material}

The datasets analysed during the current study available from the corresponding author on reasonable request.

\section{Competing interests}

The authors declare that they have no competing interests.

\section{Funding}

This research was not specifically funded by grants or any particular funding agency.

\section{Authors' contributions}

YX conceived of the study with ZYW, designed all the experiments and was a major contributor in writing the manuscript. HXW was the main participant in the experiment, responsible for data analysis and participation in writing the manuscript. SMW was responsible for project administration and provided some resources. XXW was responsible for the reproducibility of results. ZYW also provided valuable insight for designing the study and revising the manuscript.

\section{Acknowledgements}

The authors would like to thank Autobio Diagnostics Co., Ltd and Henan Provincial People's Hospital for their assistance.

\section{Author details}

${ }^{1}$ School of Life Sciences, Zhengzhou University, Zhengzhou, China. ${ }^{2}$ Zhengzhou No. 47 Middle \& High School, Zhengzhou, Henan, China. ${ }^{3}$ Department of Clinical Laboratory, Henan Provincial People's Hospital, Zhengzhou, China. ${ }^{4}$ R\&D Center, Autobio Diagnostics Co. Ltd, Zhengzhou, China.

\section{References}


1. Adam HJ, Richardson SE, Jamieson FB, Rawte P, Low DE, Fisman DN. Changing epidemiology of invasive Haemophilus influenzae in Ontario, Canada: evidence for herd effects and strain replacement due to Hib vaccination. Vaccine. 2010; 28(24):4073-8.

2. Nyambat B, Dang DA, Nguyen HA, Mai TQ, Rani M, Slack MP, Kilgore PE. Rapid assessment of Hib disease burden in Vietnam. BMC Public Health. 2011; 11:260.

3. Kalies H, Siedler A, Gröndahl B, Grote V, Milde-Busch A, von Kries R. Invasive Haemophilus influenzae infections in Germany: impact of non-type b serotypes in the post-vaccine era. BMC Infect Dis. 2009; 9:45

4. Berndsen MR, Erlendsdóttir $\mathrm{H}$, Gottfredsson M. Evolving epidemiology of invasive Haemophilus infections in the post-vaccination era: results from a long-term population-based study. Clin Microbiol Infect. 2012; 18(9):918-23.

5. Hsu MS, Wu MY, Lin TH, Liao CH. Haemophilus parainfluenzae urethritis among homosexual men. J Microbiol Immunol Infect. 2015; 48(4):450-2.

6. Sierra Y, González-Díaz A, Tubau F, Imaz A, Cubero M, Càmara J, Ayats J, Martí S, Ardanuy C. Emergence of multidrug resistance among Haemophilus parainfluenzae from respiratory and urogenital samples in Barcelona, Spain. Eur J Clin Microbiol Infect Dis. 2019; doi: 10.1007/s10096-019-03774-x.

7. Kosikowska U, Biernasiuk A, Rybojad P, Łoś R, Malm A. Haemophilus parainfluenzae as a marker of the upper respiratory tract microbiota changes under the influence of preoperative prophylaxis with or without postoperative treatment in patients with lung cancer. BMC Microbiol. 2016; 16:62.

8. Faure E, Cannesson O, Schurtz G, Coisne A, Vincentelli A, Faure K, Guery B. Haemophilus parainfluenzae endocarditis in young adults. Med Mal Infect. 2017; 47(1):58-60.

9. McCann N, Barakat MF, Schafer F (2018) An aggressive form of Haemophilus parainfluenzae infective endocarditis presenting with limb weakness. BMJ Case Rep. 2018; doi: 10.1136/bcr-2017-223775.

10. Alsuhaibani MA. Premature Infant with Haemophilus parainfluenzae Sepsis: Case Report and Literature Review. J Trop Pediatr. 2019; 65(6):638-41.

11. Hoefele J, Kroener C, Berweck S, Peraud A, Grabein B, Wintergerst U, Liese J. Haemophilus paraphrophilus, a rare cause of intracerebral abscess in children. Eur J Pediatr. 2008; 167(6):629-32.

12. Munson EL, Doern GV. Comparison of three commercial test systems for biotyping Haemophilus influenzae and Haemophilus parainfluenzae. J Clin Microbiol. 2007; 45(12):4051-3.

13. Zhang B, Kunde D, Tristram S. Haemophilus haemolyticus is infrequently misidentified as Haemophilus influenzae in diagnostic specimens in Australia. Diagn Microbiol Infect Dis. 2014; 80(4):272-3.

14. Hinz R, Zautner AE, Hagen RM, Frickmann H. Difficult identification of Hemophiliacs influenzae, a typical cause of upper respiratory tract infections, in the microbiological diagnostic routine. Eur J Microbiol Immunol (Bp). 2015; 5(1):62-7.

15. Månsson V, Resman F, Kostrzewa M, Nilson B, Riesbeck K. Identification of Haemophilus influenzae type b isolates by use of matrix-assisted laser desorption ionization-time of flight mass spectrometry. J Clin Microbiol. 2015; 53(7):2215-24.

16. Chow SK, Clarridge JE 3rd. Necessity of 16S rRNA gene sequencing for identifying Haemophilus parainfluenzae-like strains associated with opportunistic urinary tract infections. J Med Microbiol. 2014; 63(Pt 6):805-11.

17. Hosuru Subramanya S, Thapa S, Dwedi SK, Gokhale S, Sathian B, Nayak N, Bairy I. Streptococcus pneumoniae and Haemophilus species colonization in health care workers: the launch of invasive infections? BMC Res Notes. 2016; 9:66.

18. Prajapati K, Rajdev S, Mullan S. Different preservation methods for long term maintenance of Haemophilus influenzae. Adv Microbiol. 2017; 7:343-8.

19. Tebbutt GM. Evaluation of some methods for the laboratory identification of Haemophilus influenzae. J Clin Pathol. 1983; 36(9):991-5.

20. Doern GV, Chapin KC. Laboratory identification of Haemophilus influenzae: effects of basal media on the results of the satellitism test and evaluation of the RapID NH system. J Clin Microbiol.1984; 20(3):599-601.

21. Pishchany G, Sheldon JR, Dickson CF, Alam MT, Read TD, Gell DA, Heinrichs DE, Skaar EP. IsdB-dependent hemoglobin binding is required for acquisition of heme by Staphylococcus aureus. J Infect Dis. 2014; 209(11):1764-72.

22. Sjodt M, Macdonald R, Marshall JD, Clayton J, Olson JS, Phillips M, Gell DA, Wereszczynski J, Clubb RT. Energetics underlying hemin extraction from human hemoglobin by Staphylococcus aureus. J Biol Chem. 2018; 293(18):6942-57. 
23. Bennett MR, Bombardi RG, Kose N, Parrish EH, Nagel MB, Petit RA, Read TD, Schey KL, Thomsen IP, Skaar EP, Crowe JE. Human mAbs to Staphylococcus aureus IsdA provide protection through both heme-blocking and Fc-mediated mechanisms. J Infect Dis. 2019; 219(8):1264-73.

24. Evans NM, Smith DD, Wicken AJ. Haemin and nicotinamide adenine dinucleotide requirements of Haemophilus influenzae and Haemophilus parainfluenzae. J Med Microbiol. 1974; 7(3):359-65. 